\title{
Narrativa
}

\section{O crego harmónico}

\author{
Xavier Alcalá
}

Xudeus e irlandeses andan a propalar polo mundo que eles constitúen as maiores diásporas. Non lles imos discutir mérito tan triste, pois triste é sair da terra propia e perderse por lugares ignotos. Ora, hai quen pensa que os galegos gañan como poboadores de novos países, polo menos nas Américas: velas aí inzadas de apelidos da Gallaecia, como demostrou Xosé María Monterroso Devesa, o coruñés de Tacuarembó.

Ramón Piñeiro deixou frase lapidaria: os galegos son europeos por cultura, españois por Historia e mesmamente galegos por nación. Recentemente deuse no Impaís o caso dun director de cine xaponés que, no medio da contenda electoral de Cataluña, ao ver unhas cantas curtametraxes galegas en Compostela, dixo no inglés que todos entendemos: "Galicia is really a nation. Not Catalonia".

Así é. Alá a onde foren os galegos, xúntanse e relaciónanse coma tal pobo. Mesmo na fin do mundo; e unha fin do mundo ("La acabación de la Tierra" en termos de navegantes do século XVI) é o país de "los patagones", probablemente indios tehuelches, moi altos, acorporados, ben mantidos con carne de guanaco, envoltos nas peles deses camélidos únicos no Globo.

Ata a Patagonia foron chegando moitos galegos logo de que calquera día, nunha perforación á procura de auga, xurdise un chorro negro que se incendiou e matou os perforadores. A partir dese momento - a comezos do século $X X-$ iniciaríase un éxodo curioso, en parte desde Buenos Aires; despois, directamente desde Galicia, en grande proporción de terras mariñeiras pois facía falta moito persoal para navegar nos petroleiros e para ter conta da "praia" cando non había porto; finalmente, para os peiraos de petróleo e mantementos.
Cando Comodoro Rivadavia xa era unha cidade grande (duns cen mil habitantes) no medio do deserto do Chubut, a profesora Griselda Pérez e un grupo de investigación da Universidade Nacional da Patagonia fixeron un estudo sobre a endogamia galega nesa verdadeira fin de mundo, a case 2.000 quilómetros de Buenos Aires. Seica durante décadas, as familias que se ian formando observaban en detalle quen aparecía polo mar ou pola huella de pedregullo que viña do Norte. Se aparecía un rapaz galego, ou unha familia de Galicia con rapazas, empezaba o traballo das casamenteiras.

Mais polo conto que segue, non todos os galegos da capital do petróleo do Mar Austral eran solteiros en condición de casamento. Houbo casos raros coma o do "crego harmónico" que dá título á historia desta nota.

Hai en Comodoro Rivadavia un galego de especial sensibilidade nacional, que estuda finamente a historia da nación que deu apelidos ao Novo Mundo, de norte a sur, principalmente a Cuba e Arxentina. É Manuel Antonio (Cholo, ou Choliño) Rei Flórez, coruñés alá emigrado cando xa era mozo. El foi quen me proporcionou a información, e mesmo o texto básico para elaborar o conto. Débolle miles (el calcula uns 20.000) quilómetros de ver o que deixou a Darwin abraiado: o país das "paisaxes eternas", como o cualificou o xenio que mudaría as ideas da Humanidade sobre a nosa procedencia. Co meu agradecemento ao Cholo da Rúa de San Pedro da Cidade Vella da Coruña, alá vai o relato.

En Comodoro Rivadavia, nos tempos de gloria maior do petróleo e os vicios do diñeiro doado, alá polos anos 30, existía o Bar La Armonía, moi ben situado, entre a catedral e os lenocinios onde exercían as "polacas", traídas pola mafia xudía do Zgwi Migdal. O local tiña un mostrador 
ao que se arrimaba a clientela permanentemente con olladas furtivas. Por contraste, no centro da sala do bar había unhas mesas tristes, case sempre baleiras. Só sentaban nelas os que esperaban quenda, xa seguros de pasar "adentro".

Tras desta pantalla atopábanse salas con mesa e tapete, cuartos cómodos para descansar e unha cociña para os clientes de verdade. Alí, na rebotica, movíase un xogo infernal -timba, gofo, codillo, póker e dados- pero sen cartas marcadas nin cubiños "chivos" para incautos. O Armonía era un garito onde se xogaba só "a sorte e verdade", fuxindo de trampulladas como nos locais para obreiros e mariñeiros. Todo funcionaba -harmoniosamente- baixo o mando do Eufemio, empregado da casa que alternaba como repartidor de naipes e pagador na mesa de monte. El ficaba cun trinta por cento do pago, o que o fixo rico. Eufemio era un cabaleiro, recibido nas confiterías e os clubes para directivos das empresas do ouro negro. Tiña tratos coas familias ao mando do burgo que non paraba de medrar entre o deserto e a costa.

Ninguén sabía de onde chegara o Eufemio, cousa rara, pois "o servizo de información do Centro Galego" funcionaba conectado coa policía do territorio, con paisanos na nómina e comisario arousán. O fino Eufemio soamente manifestaba ser español e, por sinal, "de Galicia", nada de concello ou parroquia. Tiña as mans finas, as uñas coidadas, unha caligrafía excelente e moi boa conversa. Sendo en aparencia comunicativo, un día desapareceu da cidade sen avisalo, o cal causou grande estrañeza.

\section{¿A onde iría o home? ¿Pasaríalle algo ruín?}

No mundo do xogo e a droga (a morfina corría do porto aos bordeis alegremente) producíanse desaparicións: este, cargado de débedas, cruzaba a cordilleira cara a Chile, a aquel "baixábano" aos tiros por meter o fociño no subministro do po branco ás meretrices... Mais nada diso encaixaba no comportamento do Eufemio.

O caso é que, como dicían os patrucios do Centro Galego, «por moito que o demo cave, todo se sabe»; e unha vez máis tiveron razón.

Andaba a policía despistada co Eufemio cando se produciu outro sumicio, e este foi máis preocupante porque a sumida era unha bela moza da alta sociedade comodorense. Ausentárase con desculpa de "pasear" por Buenos Aires, o París da América do Sur, cousa comprensible pois as damas de Comodoro Rivadavia carecían de luxos e diversións como andar de tendas, teatros e cinemas na capital.

¿Que fora daquela señorita? ¿Por que a súa familia nunca falaba dela? Todos os galegos andaban coa areíña no zoco...

Pasaron os anos. De cando en cando xurdía en Comodoro Rivadavia o misterio daquelas desaparicións silandeiras. Ata que uns galegos que ían facer trámites á máis galega das avenidas da capital federal, a de Mayo, preto do famosísimo Bar 36 Billares foron bater co Eufemio en persoa, redivivo, ¡el, alí! Gastaba excelente traxe e reloxo rechamante, de ouro, a sobresaír do peto do chaleco. Acompañaba a dama tamén sumida, ela con traxe e chapeu à la parisienne. Xunto dela avanzaban dous cativos de curta idade vestidiños coma príncipes.

Houbo saúdos e ocultación de sorpresa por parte dos viaxeiros a Buenos Aires. Fixéronse preguntas sobre vellos coñecidos... e adeus. Os sorprendidos necesitaron entrar nunha confitería para tomar algo e comentar o visto: xa tiñan historia que contaren á volta...

Contárona e, daquela, os donos de La Armonía, con reticencias, completaron datos:

Había tempo que acharan na casa de xogo un antigo "baúl de camarote" que fora do Eufemio; e nel, quizais esquecida polo apuro da fuga, unha fotografía con dedicatoria "A mis queridos padres". Sotana e faixa, misal e rosario na man, un flamante padre salesiano mostraba as faccións do croupier que tanto diñeiro fixera ingresar no Armonía.

Cousas da vida na Diáspora, señores: a orde de don Bosco mandaba aos seus membros exerceren de misioneiros entre indios patagónicos e fueguinos. Mais aquel galego, que a tal mester viñera de España, deixara os hábitos, mudara o tacto das hostias polo dos naipes e fixérase amante -quen sabía se a través do confesionario- dunha señorita de boa familia. No inmenso Buenos Aires nada importaba o sacramento de Orde ante un xuíz á hora de celebrar matrimonio. E como se comentou no Centro Galego de Comodoro Rivadavia, "a maioría dos cregos non cre en Deus". 